\title{
Evaluasi Kepuasan Pengguna Terhadap Respon Cepat Tanggap Layanan Aplikasi Mobile Myindihome Berdasarkan Kombinasi Metode Servqual dan Metode Webqual
}

\author{
Endah Saputri $^{1)}$, Dedy Syamsuar ${ }^{2)}$ \\ ${ }^{12)}$ Program Pascasaarjana Magister Teknik Informatika, Universitas Bina Darma Palembang \\ Jl. Jenderal Ahmad Yani No.3, 9/10 Ulu, Kota Palembang, Sumatera Selatan 30111 \\ Email : endahsaputri@gmail.com ${ }^{1)}$, dedy_syamsuar@binadarma.ac.id ${ }^{2}$
}

\begin{abstract}
As for this research aims to determine the level of satisfaction of myindihome mobile application users. As a service provider, PT. Telkom, Tbk is required to be able to provide service, a fast respons, precise and accurate to customers. Even though it has several facilities to accommodate all customer complaints in Indonesia, but in reality there are still many customer complaints that have not been resolved properly which need attention. In this study, measurement of user satisfaction toward service responsiveness uses a combination of ServQual method and WebQual method. The combination of both theories, effectively addresses multicollinearity (if many variables are highly correlated). In connection with that condition, based on the theory of service quality (ServQual) is used to determine satisfaction with the application, is there an influence of variables of reliability, responsiveness, empathy, assurance, and tangible toward user satisfaction both individuals and groups. While based on the website quality (webqual 4.0) instrument identify quality based on three variables, namely usability, information quality, and service interaction quality. PLS (Partial Least Square) model of calculation which is one of the Structural Equation Modeling is used to test research hypothesis. Reliability and validity have also been tested. This study is also emphasis on the extent to which the perception of the quality of service of mobile applications myIndiHome perceived and how it affects the user satisfaction of mobile applications myIndiHome in this case the customer indihome that have significant impact on customers' satisfaction.
\end{abstract}

Keywords : Indihome, User Satisfaction, Servqual, and Webqual

\begin{abstract}
Abstrak
Adapun penelitian ini bertujuan untuk mengetahui tingkat kepuasan pengguna aplikasi mobile myIndiHome. Sebagai penyedia layanan, PT. Telkom, Tbk dituntut untuk mampu memberikan pelayanan atau respon yang cepat, tepat dan akurat kepada pelanggan. Meskipun memiliki beberapa sarana untuk menampung semua keluhan pelanggan di Indonesia, namun dalam kenyataannya masih banyak keluhan pelanggan yang belum dapat terselesaikan dengan baik yang perlu diperhatikan. Dalam penelitian ini, pengukuran kepuasan pengguna terhadap respon cepat tanggap layanan menggunakan kombinasi metode ServQual dan WebQual. Kombinasi kedua teori, secara efektif menangani multikolinieritas (jika banyak variabel yang sangat berkorelasi). Sehubungan dengan kondisi itu, berdasarkan teori service quality (ServQual) digunakan untuk mengetahui kepuasan terhadap aplikasi tersebut, apakah ada pengaruh variabel reliability, responsiveness, empathy, assurance, dan tangible terhadap kepuasan pengguna baik perorangan maupun kelompok. Sedangkan berdasarkan instrumen website quality (webqual 4.0) mengidentifikasi kualitas berdasarkan tiga variabel yaitu usability, information quality, dan service interaction quality. Perhitungan model PLS (Partial Least Square) yang merupakan salah satu Structural Equation Modeling (SEM) digunakan untuk menguji hipotesis penelitian. Reliabilitas dan validitas juga telah diuji. Penelitian ini juga menekankan pada sejauh mana persepsi tentang kualitas layanan aplikasi mobile myIndiHome yang dirasakan dan bagaimana pengaruhnya dengan kepuasan pengguna aplikasi mobile myIndiHome dalam hal ini pelanggan indihome yang memiliki dampak signifikan pada kepuasan pengguna.
\end{abstract}

Kata kunci : Indihome, Kepuasan Penggguna, Servqual, dan Webqual 


\section{Pendahuluan}

PT. Telkom, Tbk sebagai salah satu badan usaha yang bergerak dalam bidang jasa komunikasi. Berbagai jasa teknologi dan komunikasi yang saat ini digunakan masyarakat menjadi produk yang disediakan, salah satunya penyediaan koneksi internet. Pada saat ini, PT. Telkom, Tbk dituntut untuk meningkatkan pelayanan akan sarana dan prasarana telekomunikasi yang diperlukan oleh masyarakat khususnya konsumen atau pelanggan jasa Telkom. Hal ini, tentu saja menuntut kemampuan manajemen pelayanan untuk memberikan respon yang cepat, tepat dan akurat kepada konsumen atau pelanggan.

IndiHOME atau Indihome merupakan salah satu produk layanan dari PT. Telkom kepada masyarakat, berupa paket layanan komunikasi dan data seperti telepon rumah (voice), internet (Internet on Fiber atau High Speed Internet), dan layanan televisi interaktif (USee TV Cable, IP TV). Meskipun memiliki beberapa sarana untuk menampung semua keluhan pelanggan di Indonesia, namun dalam kenyataannya masih banyak keluhan pelanggan yang belum dapat terselesaikan dengan baik yang perlu diperhatikan (Kurniawati \& Manuputty, 2013).

Untuk melayani kebutuhan pelanggan Indihome dalam hal penanganan keluhan gangguan maupun permintaan pasang baru, Telkom menyediakan beberapa channel atau pilihan beberapa fitur agar pelanggan dapat dengan mudah berinteraksi dengan Telkom. Banyaknya jumlah pengguna Indihome yang akan terus bertambah, membuat PT. Telkom, Tbk harus meningkatkan pelayanan terhadap pelanggan baik untuk melayani pemasangan baru, penambahan layanan, migrasi paket, informasi tagihan hingga laporan keluhan gangguan layanan. Mengenai layanan tersebut sebenarnya Telkom sudah menyediakan beberapa cara untuk dapat melayani pelanggan diantaranya adalah dengan datang langsung ke Plasa Telkom terdekat atau melalui Call Center Telkom 147. Selain itu, Telkom juga menyediakan layanan berbasis aplikasi mobile yaitu aplikasi MyIndiHome. Aplikasi MyIndiHome sendiri saat ini (27/01/2019) di Google Playstore sudah mencapai 1 juta download dengan rating 3.1 dari skala 5 .

Dalam penelitian ini, untuk mengukur kepuasan pengguna terhadap respon cepat tanggap layanan aplikasi mobile myindihome menggunakan kombinasi metode ServQual dan WebQual. Berdasarkan teori metode service quality (ServQual) digunakan untuk mengetahui kepuasan terhadap aplikasi tersebut, apakah ada pengaruh variabel reliability, responsiveness, empathy, assurance, dan tangible terhadap kepuasan pengguna baik perorangan maupun kelompok (Firliana dkk., 2016). Sedangkan berdasarkan instrumen metode webqual 4.0 mengidentifikasi situs web berdasarkan tiga variabel yaitu usability, information quality, dan service interaction quality. Setiap variabel akan didukung dengan indikator-indikator yang menjadi kunci dalam penyususunan pernyataan yang akan diuji kepada responden. Maka hasil pengukuran tersebut menunjukkan bahwa jika variabel subyektif (ServQual) dari indeks usabilitas ditingkatkan, maka variabel obyektif dari indeks usabilitas (WebQual) juga akan meningkat secara signifikan(Hermanto dkk., 2017)

\section{A. Metodologi Penelitian}

1. Model Penelitian

Pada Gambar 1 menunjukkan model yang digunakan dalam penelitian ini. Terdapat delapan variabel independent $(\mathrm{X})$ yang menentukan variabel dependent (Y). Adapun definisi operasional yang digunakan dalam penelitian ini dapat dilihat pada Lampiran Gambar 1.

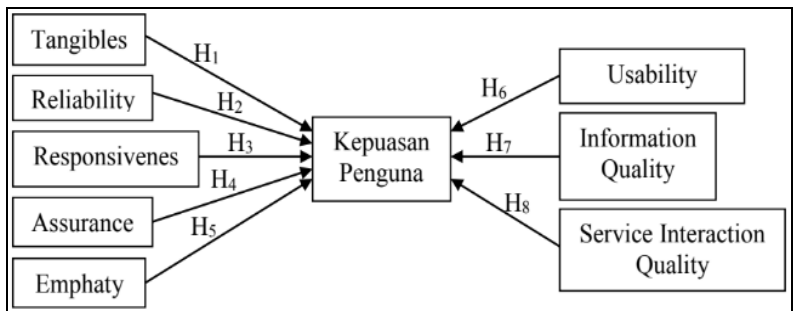

Gambar 1. Model Konseptual Pengukuran Penelitian

\section{Data Penelitian}

Pengumpulan data pada penelitian ini menggunakan terknik survey yaitu dengan menyediakan Kuesioner (Questionnaire). Metode yang digunakan yaitu Purposive Sampling. Teknik pemilihan sampel ketika peneliti tidak memiliki data tentang populasi dalam bentuk sampling frame dan peneliti kemudian memilih sampel berdasarkan kriteria-kriteria tertentu dan penilaian peneliti untuk mengarahkan sampel terpilih sesuai dengan tujuan penelitian. Pengambilan sampel ini menentukan keakuratan dan ketepatan penentuan sumber data dan informasi bagi proses analisis dan pengambilan kesimpulan.

Disini pelanggan mengisi kuesioner yang diberikan peneliti. Peneliti menyebarkan kuesioner tersebut dari pelanggan satu ke pelanggan lainnya. Dari usaha pengumpulan data tersebut, maka diperoleh sekitar 200 respon. Menurut Barclay dkk. (1995) menyatakan bahwa "jumlah sampel harus lebih besar dari 10 kali jumlah variabel yang diamati”. Pada penelitian ini ada 9 variabel, sehingga jumlah sampel adalah minimal 90 responden. Untuk lebih menyakinkan secara statistik, penelitian ini juga akan menguji kecukupan jumlah responden berdasarkan saran dari Hair dkk. (2010) yaitu menggunakan Kaiser-Meyer-Olkin Measure of Sampling Adequacy (KMOMSA) dan Bartlett's Test of Sphericity (BToS). Nilai KMO antara 0,5 - 1 menunjukan jumlah sampel telah memadai. Berdasarkan nilai, mereka mengkategorikan ukuran sebagai luar biasa $(0,90$-an), sangat baik $(0,80$-an), baik (0,70-an), cukup (0,60-an) dan menyedihkan (0,50-an). Jika BToS kurang dari 0,05 , kecukupan sampel signifikan.

3. Teknik Analisis Data

Penelitian ini melihat secara objektif persepsi pelanggan terhadap layanan yang diberikan oleh pihak PT. Telkom, Tbk., sehingga penelitian ini digolongkan pada penelitian kuantitatif. Data yang dikumpulkan akan 
dianalisis menggunakan Teknik Analisis Data Kuantitatif.

Pada bagian ini menyajikan analisis data menggunakan Structural Equation Modelling (SEM), lebih khusus lagi menggunakan Partial Least Squares (PLS) untuk mengevaluasi model yang diusulkan. Ada dua langkah untuk uji validitas dan reliabilitas untuk membangun model dalam SEM menggunakan PLS. Menurut Hair dkk. (2016) secara garis besar ada dua tahap analisis data yaitu Measurement Model Analysis dan Structural Model Analysis. Sebelum dilakukan analisis tersebut, penulis akan melakukan persiapan data (data preparation) yang bertujuan membersihkan data dari hal-hal yang dapat mempengaruhi hasil. Analisis implementasi model dilakukan berdasarkan model yang telah dibuat sebelumnya. Tahapan dalam analisis ini terdiri dari 3 tahapan yaitu :

a. Pengujian asumsi SEM yaitu memeriksa missing value, memeriksa kecukupan data(data adequacy), keseriusan responden(unengaged value), evaluasi outlier, dan evaluasi normalitas.

b. Pengujian model pengukuran (measurement model validity) yaitu melakukan analisis faktor konfirmatori (CFA) untuk setiap variabel laten eksogen dan endogen kemudian dilanjutkan pengujian full model.

c. Pengujian structural model validity dengan melakukan validitas dan realibitas data. Uji validitas dilakukan dengan uji convergent validity dan discriminant validity.

\section{Pembahasan}

\section{A. Deskripsi Responden}

Berdasarkan penyebaran kuesioner terhadap 200 responden yang merupakan pelanggan indihome Kota Palembang dapat diketahui gambaran tentang usia, pendidikan, dan pekerjaan responden yang dijadikan sampel.

1. Deskripsi Usia Responden

Berdasarkan data penelitian yang diperoleh dari penyebaran kuesioner maka diperoleh data tentang usia pengguna indihome Kota Palembang yang menjadi respon dalam penelitian ini, seperti berikut:

Tabel 1. Deskripsi Usia Responden

\begin{tabular}{|c|c|c|c|}
\hline No. & $\begin{array}{c}\text { Umur } \\
\text { (tahun) }\end{array}$ & Jumlah & $\begin{array}{c}\text { Persentase } \\
(\boldsymbol{\%})\end{array}$ \\
\hline 1. & $12-18$ & 29 & $15 \%$ \\
\hline 2. & $19-24$ & 32 & $16 \%$ \\
\hline 3. & $25-30$ & 48 & $24 \%$ \\
\hline 4. & $31-40$ & 39 & $20 \%$ \\
\hline 5. & $41-50$ & 29 & $15 \%$ \\
\hline 6. & $>51$ & 23 & $12 \%$ \\
\hline \multicolumn{2}{|c|}{ Total } & 200 & $100 \%$ \\
\hline
\end{tabular}

Tabel berikut menunjukkan bahwa sebagian besar usia pengguna indihome Kota Palembang dalam penelitian ini yang paling banyak menggunakan tingkatan umur 25 - 30 tahun sebanyak 48 pengguna. Data tersebut bisa dijadikan masukan kepada pihak penyedia jasa layanan indihome untuk lebih memperhatikan solusi keluhan yang seperti apa yang tepat bagi pengguna indihome.

\section{Deskripsi Pendidikan Responden}

Berdasarkan data penelitian yang diperoleh dari penyebaran kuesioner maka diperoleh data tentang pendidikan pengguna indihome Kota Palembang yang menjadi respon dalam penelitian ini, seperti berikut:

Tabel 2. Deskripsi Pendidikan Responden

\begin{tabular}{|c|c|c|c|}
\hline No. & Pendidikan & Jumlah & $\begin{array}{c}\text { Persentase } \\
(\%)\end{array}$ \\
\hline 1. & SD & 12 & $6 \%$ \\
\hline 2. & SMP & 17 & $9 \%$ \\
\hline 3. & SMA & 53 & $27 \%$ \\
\hline 4. & D3 & 2 & $1 \%$ \\
\hline 5. & D4/S1 & 106 & $53 \%$ \\
\hline 6. & S2 & 10 & $5 \%$ \\
\hline \multicolumn{2}{|c|}{ Total } & 200 & $100 \%$ \\
\hline
\end{tabular}

Tabel berikut menunjukkan bahwa sebagian besar pendidikan pengguna indihome dalam penelitian ini memiliki pendidikan S1 sebanyak 106 orang, sedangkan yang pendidikan SMA sebanyak 53 orang. Hal ini untuk perrhatian bagi penyedia jasa layanan indihome, bahwa pengguna indihome mayoritas berpendidikan antara SMA dan S1. Oleh karena itu lebih mengerti seperti apa yang diminati oleh pengguna indihome.

\section{B. Data Preparation/Screening}

Data yang perlu disiapkan, diperiksa dan dieksplorasi sebelum melakukan analisis data statistik lebih lanjut. Langkah ini melibatkan entri data dan data screening berupa memeriksa missing value, memeriksa kecukupan data(data adequacy), keseriusan responden(unengaged value), outlier, dan pengujian normalitas data. Berikut penguraiannya:

1. Pada tahap missing value, tidak ditemukan missing data dalam dataset, sehingga semua data dapat dilakukan pengujian selanjutnya.

2. Pada tahap data adequacy, tes menunjukkan bahwa nilai KMOMSA dan BToS masing-masing adalah 0,692 dan 0,000. Oleh karena itu, ukuran sampel dianggap cukup besar untuk mencapai daya yang cukup untuk efek yang diamati.

3. Pada tahap unengaged value yaitu pengujian keseriusan tidak ditemukan respon yang merespon dengan jawaban yang sama. Menurut Hair dkk. (2010) menjelaskan bahwa data yang hilang terjadi ketika nilai yang valid pada satu atau lebih variabel tidak tersedia untuk analisis.

4. Pada tahap outlier, penelitian ini menunjukkan nilai mahalonabis distance $\chi^{2}(34,0,001)=66,25$. Hal ini berarti semua indikator yang mempunyai mahalonobis distance yang lebih besar dari 66,25 adalah multivariate outliers. Semua indikator pada penelitian ini memiliki nilai mahalonabis distance di bawah 66,25 sehingga tidak ada outliers pada data. 
5. Dan pada tahap normalitas, skewness dan kurtosis dari kurva normal memiliki nilai nol; nilai skewness atau nilai kurtosis di atas atau di bawah nol menunjukkan penyimpangan dari normalitas. Nilai yang paling dapat diterima untuk dua statistik adalah antara -2 dan +2 . Peneliti menemukan banyak variasi nilai yang dapat diterima di antara para peneliti. Hasil pengolahan data memperlihatkan bahwa tidak ada satupun nilai univariate yang berada diluar rentang nilai $\pm 2,58$ maka dari itu data dikatakan berdistribusi normal. Berikut tabel pengujian ditunjukkan pada tabel 3, antara lain:

Tabel 3. Pengujian Normalitas Data

\begin{tabular}{|c|c|c|c|c|c|c|}
\hline & Mean & $\begin{array}{c}\text { Std. } \\
\text { Deviation }\end{array}$ & \multicolumn{2}{|c|}{ Skewness } & \multicolumn{2}{|c|}{ Kurtosis } \\
\cline { 2 - 7 } & Statistic & Statistic & Statistic & $\begin{array}{c}\text { Std. } \\
\text { Error }\end{array}$ & Statistic & $\begin{array}{c}\text { Std. } \\
\text { Error }\end{array}$ \\
\hline RL1 & 2,95 & 0,608 & $-0,383$ & 0,172 & 0,960 & 0,342 \\
\hline RL2 & 2,92 & 0,616 & $-0,078$ & 0,172 & $-0,010$ & 0,342 \\
\hline RL3 & 2,87 & 0,607 & 0,073 & 0,172 & $-0,353$ & 0,342 \\
\hline RL4 & 2,91 & 0,555 & $-0,041$ & 0,172 & 0,193 & 0,342 \\
\hline RP1 & 2,82 & 0,640 & $-0,287$ & 0,172 & 0,327 & 0,342 \\
\hline RP2 & 2,92 & 0,608 & $-0,364$ & 0,172 & 0,833 & 0,342 \\
\hline RP3 & 2,90 & 0,673 & $-0,180$ & 0,172 & $-0,051$ & 0,342 \\
\hline RP4 & 2,73 & 0,655 & 0,129 & 0,172 & $-0,424$ & 0,342 \\
\hline AS1 & 2,84 & 0,544 & $-0,092$ & 0,172 & 0,087 & 0,342 \\
\hline AS2 & 2,76 & 0,604 & $-0,117$ & 0,172 & $-0,023$ & 0,342 \\
\hline AS3 & 2,96 & 0,494 & $-0,102$ & 0,172 & 1,121 & 0,342 \\
\hline AS4 & 2,74 & 0,562 & $-0,320$ & 0,172 & 0,141 & 0,342 \\
\hline EP1 & 2,87 & 0,514 & $-0,188$ & 0,172 & 0,509 & 0,342 \\
\hline EP2 & 2,90 & 0,567 & $-0,351$ & 0,172 & 1,015 & 0,342 \\
\hline EP3 & 2,72 & 0,660 & 0,067 & 0,172 & $-0,328$ & 0,342 \\
\hline EP4 & 2,84 & 0,544 & $-0,281$ & 0,172 & 0,570 & 0,342 \\
\hline T1 & 2,98 & 0,609 & 0,010 & 0,172 & $-0,274$ & 0,342 \\
\hline T2 & 3,05 & 0,689 & $-0,059$ & 0,172 & $-0,879$ & 0,342 \\
\hline T3 & 2,99 & 0,683 & $-0,077$ & 0,172 & $-0,563$ & 0,342 \\
\hline T4 & 3,00 & 0,634 & $-0,358$ & 0,172 & 0,672 & 0,342 \\
\hline USA1 & 2,86 & 0,653 & $-0,283$ & 0,172 & 0,298 & 0,342 \\
\hline USA2 & 2,93 & 0,593 & $-0,127$ & 0,172 & 0,276 & 0,342 \\
\hline USA3 & 2,85 & 0,627 & 0,002 & 0,172 & $-0,239$ & 0,342 \\
\hline USA4 & 2,97 & 0,588 & $-0,144$ & 0,172 & 0,411 & 0,342 \\
\hline USA5 & 2,82 & 0,635 & $-0,064$ & 0,172 & $-0,112$ & 0,342 \\
\hline USA6 & 2,97 & 0,584 & $-0,303$ & 0,172 & 0,977 & 0,342 \\
\hline IQ1 & 2,84 & 0,565 & $-0,187$ & 0,172 & 0,310 & 0,342 \\
\hline IQ2 & 2,89 & 0,513 & $-0,174$ & 0,172 & 0,597 & 0,342 \\
\hline IQ3 & 2,95 & 0,472 & $-0,175$ & 0,172 & 1,469 & 0,342 \\
\hline IQ4 & 2,85 & 0,602 & 0,077 & 0,172 & $-0,349$ & 0,342 \\
\hline SIQ1 & 2,87 & 0,564 & $-0,024$ & 0,172 & $-0,003$ & 0,342 \\
\hline SIQ2 & 2,89 & 0,513 & $-0,174$ & 0,172 & 0,597 & 0,342 \\
\hline SIQ3 & 3,06 & 0,651 & $-0,165$ & 0,172 & $-0,240$ & 0,342 \\
\hline SIQ4 & 2,93 & 0,665 & $-0,124$ & 0,172 & $-0,180$ & 0,342 \\
\hline USF1 & 2,96 & 0,566 & $-0,010$ & 0,172 & 0,157 & 0,342 \\
\hline USF2 & 3,00 & 0,597 & $-0,141$ & 0,172 & 0,326 & 0,342 \\
\hline
\end{tabular}

\section{Analisis Data}

Bagian ini melaporkan hasil survei, dengan menggunakan berbagai metode statistik untuk analisis data struktural yang didukung berdasarkan variabelvariabel terkait.

\section{Measurement Model Validity (AVE/CFA)}

Penilaian model pengukuran validitas melibatkan (1) realibilitas indikator, (2) reliabilitas konsistensi internal, dan (3) validitas konstruk. Analisis model pengukuran (measurement model) menggunakan analisis faktor konfirmatori (confirmatory factor analysis/CFA) dimaksudkan untuk mengkonfirmasi semua indikator yang membentuk tiap-tiap konstruk. Setelah dilakukan konfirmatori faktor untuk tiap konstruk maka dilakukan pengukuran keseluruhan model. Untuk tujuan ini, penelitian ini terutama digunakan SmartPLS dan dikombinasikan dengan SPSS dan Excel bila diperlukan. 1) Pada tahap realibilitas indikator, nilai 0,70 atau lebih besar dapat diterima untuk mencapai tingkat kepuasan. Namun, nilai yang lebih tinggi dari 0,95 dipertanyakan karena menunjukkan multikolinieritas dan kemungkinan bahwa responden belum menjawab secara objektif (Tabachnick \& Fidell, 2001). Hasil analisis disajikan pada Tabel yang juga mengungkapkan bahwa beberapa indikator berada di bawah nilai yang diinginkan dari 0,7 , sebagai berikut:

Tabel 4. Penilaian Cross Loading

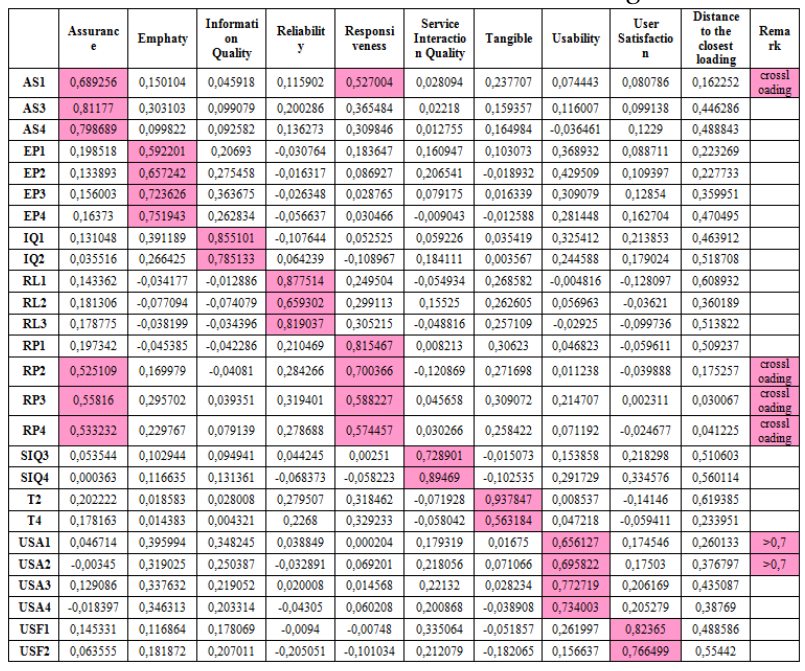

2) Realibilitas konsistensi internal

Hair dkk. (2010) menjelaskan bahwa konsistensi internal adalah persyaratan keandalan dalam konstruksi reflektif. Selanjutnya, Hair dkk. (2014) menyarankan penggunaan reliabilitas komposit untuk menggantikan alpha Cronbach tradisional untuk menentukan reliabilitas konsistensi internal. Beberapa penelitian seperti dilansir Hair dkk. (2012), gabungkan keduanya untuk memastikan tingkat validitas yang tinggi. Untuk nilai yang dapat diterima, Cronbach's alpha dapat diterima jika itu 0,6 atau lebih tinggi, sedangkan Hair dkk. (2010) merekomendasikan 0,5 atau lebih tinggi untuk memungkinkan keandalan Komposit diterima. Tabel 5 menunjukkan bahwa baik keandalan Komposit dan Alpha Cronbach untuk semua konstruksi memuaskan dan di atas ambang batas yang disarankan. Tingkat keandalan konsistensi internal yang tinggi telah ditunjukkan oleh semua konstruk yang menunjukkan bahwa setiap item memiliki konsistensi internal yang kuat dengan item konstruk lainnya. 
Tabel 5. Outer Model Reliability dan Validity

\begin{tabular}{|l|c|c|c|c|}
\hline & AVE & $\begin{array}{c}\text { Composite } \\
\text { Reliability }\end{array}$ & $\begin{array}{c}\text { R } \\
\text { Square }\end{array}$ & $\begin{array}{c}\text { Cronbachs } \\
\text { Alpha }\end{array}$ \\
\hline Assurance & 0,59065 & 0,811554 & & 0,659233 \\
\hline Emphaty & 0,46793 & 0,777236 & & 0,629443 \\
\hline $\begin{array}{l}\text { Information } \\
\text { Quality }\end{array}$ & 0,673816 & 0,80484 & & 0,518816 \\
\hline Reliability & 0,625177 & 0,831528 & & 0,730298 \\
\hline Responsiveness & 0,457878 & 0,767901 & & 0,706335 \\
\hline $\begin{array}{l}\text { Service } \\
\text { Interaction } \\
\text { Quality }\end{array}$ & 0,665883 & 0,797767 & & 0,514479 \\
\hline Tangible & 0,598366 & 0,737182 & & 0,388918 \\
\hline Usability & 0,512632 & 0,807392 & & 0,682263 \\
\hline $\begin{array}{l}\text { User } \\
\text { Satisfaction }\end{array}$ & 0,63296 & 0,775005 & 0,22022 & 0,421606 \\
\hline
\end{tabular}

\section{3) Validitas Konstruk}

Dalam bagan ini, diuji dengan validitas konvergen dan diskriminan. Untuk memeriksa validitas diskriminan di tingkat konstruksi adalah dengan melakukan analisis Kriteria Forner-Larker. Prosedur ini menunjukkan bahwa rasio akar kuadrat dari AVE masing-masing konstruk dengan korelasi konstruk dengan semua konstruk lainnya dapat digunakan untuk menetapkan validitas diskriminan. Akar kuadrat dari nilai AVE harus lebih besar daripada korelasi dengan konstruksi lainnya (Hair dkk., 2014). Hasil pada Tabel 6 menunjukkan bahwa validitas diskriminan sudah mapan untuk semua konstruksi. Oleh karena itu, disimpulkan bahwa proses validitas model pengukuran menunjukkan tingkat substansial dari validitas konvergen dan diskriminan yang dibenarkan melanjutkan dengan validitas model struktural dan pengujian hipotesis.

Tabel 6. Analisis Kriteria Fornell-Larcker

\begin{tabular}{|c|c|c|c|c|c|c|c|c|c|}
\hline & Assurance & Emphaty & $\begin{array}{c}\text { Informati } \\
\text { on } \\
\text { Quality }\end{array}$ & Reliability & $\begin{array}{l}\text { Respon } \\
\text { siveness }\end{array}$ & $\begin{array}{c}\text { Serrice } \\
\text { Interactio } \\
\text { nQuality }\end{array}$ & Tangible & Usability & $\begin{array}{c}\text { User } \\
\text { Satisfacti } \\
\text { on }\end{array}$ \\
\hline Assurance & 1,000000 & & & & & & & & \\
\hline Emphaty & 0,232348 & 1,000000 & & & & & & & \\
\hline $\begin{array}{l}\text { Information } \\
\text { Quality }\end{array}$ & 0,10631 & 0,406134 & 1,000000 & & & & & & \\
\hline Reliability & 0,196174 & $-0,05037$ & $-0,035618$ & 1,000000 & & & & & \\
\hline $\begin{array}{l}\text { Responsivene } \\
\text { ss }\end{array}$ & 0,498843 & 0,101401 & $-0,025586$ & 0,335979 & $\begin{array}{c}1,00000 \\
0\end{array}$ & & & & \\
\hline $\begin{array}{l}\begin{array}{l}\text { Service } \\
\text { Interaction } \\
\text { Quality }\end{array} \\
\end{array}$ & 0,02576 & 0,134136 & 0,141072 & $-0,02883$ & $\frac{0,04129}{5}$ & 1,000000 & & & \\
\hline Tangible & 0,235911 & 0,020968 & 0,025394 & 0,319114 & $\frac{0,38891}{8}$ & $-0,082005$ & 1,000000 & & \\
\hline Usability & 0,055623 & 0,486286 & 0,350554 & $-0,006751$ & $\begin{array}{c}0,05035 \\
8\end{array}$ & 0,286159 & 0,024156 & 1,000000 & \\
\hline $\begin{array}{l}\text { User } \\
\text { Satisfaction }\end{array}$ & 0,134258 & 0,184913 & 0,240498 & $-0,126933$ & 0,06444 & 0,348112 & $-0,1417$ & 0,266789 & 1,000000 \\
\hline
\end{tabular}

\section{4) Structural Model Validity}

Model pengukuran telah divalidasi melalui proses yang ketat secara sistematis pada bagian sebelumnya. Hasilnya menunjukkan bahwa semua properti penilaian reliabilitas dan validitas berada dalam rentang kesalahan yang dapat diterima. Hasil uji normalitas juga menunjukkan bahwa ada beberapa masalah dengan normalitas. Chin (2010) merekomendasikan estimasi PLS untuk kasus distribusi variabel yang tidak normal. Model struktural dinilai untuk menentukan kekuatan penjelas dari model serta untuk menguji hipotesis penelitian.

Menghitung signifikansi nilai-t untuk koefisien jalur dan nilai-p untuk mengukur tingkat signifikansi. Seperti yang disarankan oleh Hair dkk. (2014), nilai persyaratan umum adalah 1,65, 1,96 dan 2,57 dari nilai uji-t pada tingkat nilai $\mathrm{p}$ yang signifikan masing-masing $0,10,0,05$ dan 0,01. Signifikansi statistik dari koefisien jalur dibuat menggunakan bootstrap (Sign Changes = No Sign Changes, Cases $=1000$, Sample $=200$ ) Menghibur.

Hasil pengujian hipotesis dirangkum dalam Tabel 7 yang menunjukkan bahwa koefisien service interaction quality $(8,759399)$ memiliki dampak terbesar pada kepuasan pengguna, dan diikuti oleh assurance $(5,898632)$ dan usality $(4,771422)$ masing-masing. Sebaliknya, emphaty $(0,396939)$ berada di bawah nilai ambang batas dan oleh karena itu mereka tidak berkontribusi secara statistik untuk menjelaskan kepuasan pengguna. Konsisten dengan uji koefisien jalur, Tabel 7.12 juga menunjukkan bahwa nilai uji-t dari variabel independen (kepuasan pengguna) memiliki pengaruh signifikan terhadap variabel dependen(servqual dan webqual). Tes juga menunjukkan bahwa koefisien jalur responsiveness dalam kaitannya dengan kepuasan pengguna tidak menunjukkan efek yang bermakna $(1,439232)$. Hasil uji signifikan dari koefisien jalur model dapat dilihat pada tabel 6 dibawah ini :

Tabel 7. Pengujian Signifikansi dari Koefisien Jalur Model Struktural

\begin{tabular}{|c|c|c|c|c|c|}
\hline & $\begin{array}{c}\text { Original } \\
\text { Sample } \\
\text { (O) }\end{array}$ & $\begin{array}{c}\text { Sample } \\
\text { Mean } \\
\text { (M) }\end{array}$ & $\begin{array}{l}\text { Standard } \\
\text { Deviation } \\
\text { (STDEV) }\end{array}$ & $\begin{array}{l}\text { Standard } \\
\text { Error } \\
\text { (STERR) }\end{array}$ & $\begin{array}{l}\text { T Statistics } \\
\text { (|O/STERR|) }\end{array}$ \\
\hline $\begin{array}{l}\text { Assurance }> \\
\text { User Satisfaction }\end{array}$ & 0,191009 & 0,194842 & 0,032382 & 0,032382 & 5,898632 \\
\hline $\begin{array}{l}\text { Emphaty > User } \\
\text { Satisfaction }\end{array}$ & $\begin{array}{c}- \\
0,015512\end{array}$ & $-0,00943$ & 0,039078 & 0,039078 & 0,396939 \\
\hline $\begin{array}{l}\text { Information } \\
\text { Quality > User } \\
\text { Satisfaction }\end{array}$ & 0,13528 & 0,137038 & 0,028736 & 0,028736 & 4,707608 \\
\hline $\begin{array}{l}\text { Reliability }> \\
\text { User Satisfaction }\end{array}$ & $\begin{array}{c}- \\
0,089826\end{array}$ & $\begin{array}{c}- \\
0,088933 \\
\end{array}$ & 0,028995 & 0,028995 & 3,097992 \\
\hline $\begin{array}{l}\text { Responsiveness - } \\
>\quad \text { User } \\
\text { Satisfaction }\end{array}$ & $\begin{array}{c}- \\
0,076847\end{array}$ & 0,084693 & 0,053395 & 0,053395 & 1,439232 \\
\hline $\begin{array}{l}\text { Service } \\
\text { Interaction } \\
\text { Quality > User } \\
\text { Satisfaction }\end{array}$ & 0,269658 & 0,270759 & 0,030785 & 0,030785 & 8,759399 \\
\hline $\begin{array}{l}\text { Tangible }>\text { User } \\
\text { Satisfaction }\end{array}$ & $\overline{0} \overline{-} 112713$ & $\begin{array}{c}- \\
0,116472\end{array}$ & 0,028925 & 0,028925 & 3,896807 \\
\hline $\begin{array}{l}\text { Usability > User } \\
\text { Satisfaction }\end{array}$ & 0,145105 & 0,143349 & 0,030411 & 0,030411 & 4,771422 \\
\hline
\end{tabular}

Model struktural dalam PLS-SEM ditentukan dengan menilai kekuatan penjelas dari model struktural dan koefisien jalur. Pengujian jalur sebelumnya menunjukkan bahwa variabel independen (kepuasan pengguna) sangat berkorelasi dengan variabel dependen (servqual dan webqual). Seperti yang disarankan oleh Hair dkk. (2014), studi saat ini menilai kekuatan penjelas dari model dengan menghitung korelasi kuadrat ganda $\left(\mathrm{R}^{2}\right)$.

Menurut Hair dkk. (2010), level $\mathrm{R}^{2}$ penting dalam menilai model struktural. Chin (2010) merekomendasikan bahwa nilai $\mathrm{R}^{2} 0,67,0,33$ atau 0,19 untuk variabel laten endogen dalam model bagian dalam digambarkan sebagai substansial, sedang atau lemah masing-masing. Hasilnya menunjukkan bahwa $\mathrm{R}^{2}$ untuk resistensi terhadap perubahan adalah 0,220. Ini berarti bahwa variabel laten memuaskan menjelaskan $22 \%$ dari varians dalam kepuasan pengguna berpengaruh pada variabel dependen. Model akhir dan ringkasan pengujian hipotesis disajikan sebagai berikut: 


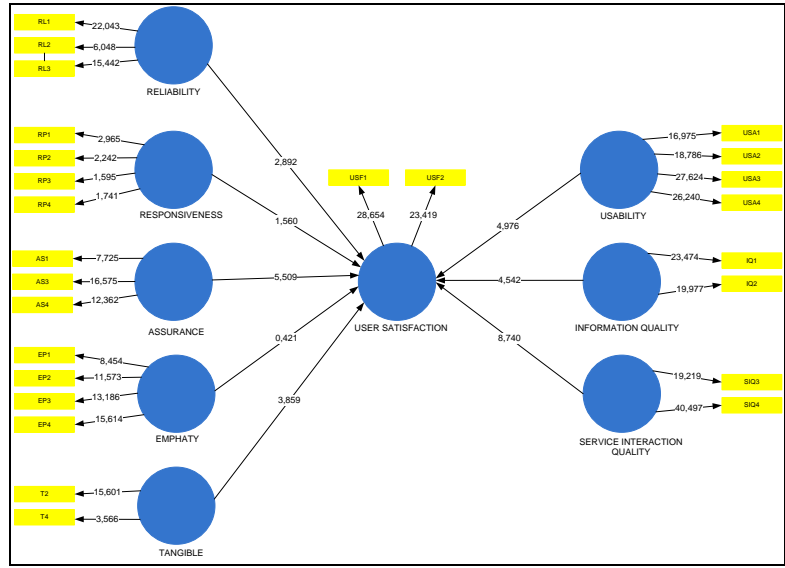

Gambar 2. Hasil Pengukuran Full Model Penelitian Bootstrapping

Pengukuran model dengan CFA masing-masing variabel laten menghasilkan model yang fit seperti yang terlihat pada tabel 2 diatas. Setelah semua CFA masingmasing variabel laten fit maka dilakukan pengukuran full model kualitas layanan website. Hasil pengukuran ini ternyata tidak menghasilkan model yang fit dengan nilai $\mathrm{p}=0,000$. Gambar 2 merupakan hasil pengukuran full model yang telah di modifikasi indeks.

\section{Kesimpulan}

Berdasarkan hasil analisis dan penelitian yang telah dilakukan, didapat kesimpulan sebagai berikut:

1. Hasil data yang dikumpulkan dalam penelitian ini diolah untuk memperoleh indeks usabilitas kuantitatif dan indeks kuantitatif subjektif dengan menerapkan pemodelan persamaan struktural. Hasil pengolahan menunjukkan bahwa jika dimensi kepuasan (tindakan subjektif dari indeks usabilitas) ditingkatkan, maka ukuran obyektif indeks usabilitas dapat meningkatkan secara signifikan.

2. Hasil penelitian ini menunjukkan bahwa aspek-aspek obyektif dan subjektif yang menjadi faktor penilaian usabilitas mendapatkan hasil yang baik dan memuaskan dari hampir semua responden dalam menggunakan layanan aplikasi mobile myIndiHome.

3. Berdasarkan hasil analisis data kepuasan pengguna terdapat pada grafik tingkat kepuasan pengguna mengenai layanan aplikasi mobile myindihome berdasarkan dimensi servqual dan webqual. Yang berada pada kriteria puas yaitu service interaction quality dan usability dari dimensi variabel webqual dengan rata-rata hasil pengujian 8,759399 dan 4,771422 serta assurance dari dimensi variabel servqual dengan rata-rata hasil pengujian 5,898632. Sedangkan yang berada pada kriteria tidak puas yaitu emphaty dengan rata-rata hasil pengujian 0,396939.

\section{Saran}

Adapun saran penulis yang diharapkan dapat memberikan perbaikan dalam peneliitian selanjutnya adalah sebagai berikut:
1. Merinci indikator lebih banyak dan lebih dalam variabel user satisfaction.

2. Mengelompokkan responden sesuai dengan tingkat penggunaan indihome ysng dinilai.

3. Memberikan kolom saran pada kuisioner sehingga hasil masukan tidak hanya berupa variabel yang ditentukan saja melainkan juga masukan langsung dari responden.

4. Menggunakan uji validitas dan reliabel ataupun teknik perhitungan yang lain sehingga dapat dibandingkan hasilnya.

\section{Daftar Pustaka}

Barclay, D., Higgins, C., \& Thompson, R. 1995. The partial least squares (PLS) approach to casual modeling: personal computer adoption ans use as an Illustration. Technology Studies, 2(2).

Barnes, S. J., \& Vidgen, R. T. 2002. An integrative approach to the assessment of e-commerce quality. Journal of Electronic Commerce Research, 3(3), 114-127.

Chin, W. W. (2010). How to write up and report PLS analyses. In Handbook of partial least squares (pp. 655-690). Springer, Berlin, Heidelberg..

DeLone, W. H., \& McLean, E. R. 2003. The DeLone and McLean model of information systems success: a ten-year update. J Journal of management information systems, 19(4), 9-30.

Firliana, R., Kasih, P., \& Sulastri, H. S. 2016. Sistem Analisis Kualitas Pelayanan terhadap Tingkat Kepuasan Pelanggan menggunakan Metode Service Quality (SERVQUAL). Seminar Nasional Teknologi Informasi dan Multimedia (semnasteknomedia online), 4(1), 205-210.

Hair, J. F., Anderson, R. E., Babin, B. J., \& Black, W. C. 2010. Multivariate data analysis: A global perspective (Vol. 7): Upper Saddle River, NJ: Pearson.

Hair, J. F., Hult, G. T. M., Ringle, C. M., \& Sarstedt, M. 2016. A Primer on Partial Least Squares Structural Equation Modeling (PLS-SEM): SAGE Publications.

Hermanto, A., Supangat, S., \& Mandita, F. 2017. Evaluasi Usabilitas Layanan Sistem Informasi Akademik Berdasarkan Kombinasi ServQual dan Webqual Studi Kasus: SIAKAD Politeknik XYZ. Journal of Information Systems Engineering and Business Intelligence, 3(1), 33-39.

Kurniawati, R., \& Manuputty, A. D. 2013. Analisis Kualitas Layanan Teknologi Informasi dengan Menggunakan Framework Information Technology Infrastructure LibraryV. 3 (ITIL V. 3) DomainService Transition: Studi Kasus pada Costumer Service Area Telkom Salatiga. Jurnal Teknologi Informasi -Aiti, 10(1), 31-45.

Parasuraman, A., Zeithaml, V. A., \& Berry, L. L. (1988). Servqual: A multiple-item scale for measuring consumer perc. Journal of Retailing, 64(1), 12. 
Syamsuar, D. 2015. Understanding IPv6 resistance: A model of resistance among Indonesian organizations (Doctoral dissertation, Curtin University). 